\title{
A COGNITIVE-LINGUISTIC INVESTIGATION OF ENGLISH PHRASAL VERBS RELATED TO PLANTS
}

\author{
UDC 811.111'367.625 \\ 811.111 '37
}

\author{
Ivan Milošević ${ }^{1}$, Tijana Vesić Pavlović \\ ${ }^{1}$ The College of Hotel Management, Belgrade, Serbia \\ ${ }^{2}$ University of Belgrade, Faculty of Mechanical Engineering, Belgrade, Serbia
}

\begin{abstract}
The focus of the paper is on the semantics of English phrasal verbs whose constituent verb is related to the concept of PLANTS. The investigated set of verbs includes twenty-two phrasal verbs featuring the particles OUT, OFF, UP, THROUGH, IN and AWAY. The analysis is conducted in the framework of cognitive semantics, which states that the meaning of phrasal verbs can be analysed in view of their constituent particles and the interplay between the verb meaning and the particle senses. It is concluded that the general meaning of the examined phrasal verbs is a result of different spatial configurations underlying the conceptual-semantic structure of the constituent particles, while their specific meanings are motivated by different conceptual metonymies stemming from the constituent verb. Numerous abstract meanings are additionally derived via various submetaphors of the basic metaphor COMPLEX ABSTRACT SYSTEMS ARE PLANTS embedded in the conceptual framework of the constituent verbs.
\end{abstract}

Key words: phrasal verbs, plants, cognitive semantics, spatial configurations, conceptual mechanisms.

\section{INTRODUCTION}

Traditionally, the meaning of phrasal verbs has been observed as highly arbitrary and nontransparent. Authors such as Live (1965), Anastasijević (1968) or Fraser (1976) did not perceive phrasal verbs in the light of their semantics, but focused their research efforts on their syntactic structure. As a result, the analysis of the meaning of these linguistic units has not been systematic. This has led to phrasal verbs being perceived by learners as "perennial sources of confusion" and "major obstacles on the path to proficiency in English" (Yasuda 2010: 250). However, the advent of studies such as Brugman's (1981) or Lindner's (1981), modelled on the Langacker's 'Space Grammar' concept (later elaborated in Langacker 1987),

Submitted July $14^{\text {th }} 2017$, accepted for publication October $11^{\text {th }}, 2017$

Corresponding author: Tijana Vesić Pavlović

Faculty of Mechanical Engineering, Belgrade, Kraljice Marije 16, 11120 Belgrade, Serbia

E-mail: tvesic@mas.bg.ac.rs 
has enabled a more systematic examination of the phrasal verbs' semantic structure centred on the meaning of their constituent particles. These authors have emphasized that the semantic analysis of lexical units such as phrasal verbs is a matter of motivation and partial compositionality, i.e. that the meaning of phrasal verbs is not a result of arbitrary relations between words but comes from various cognitive mechanisms stemming from their conceptual-semantic framework, such as conceptual metaphor and metonymy.

The present paper investigates the semantics of English phrasal verbs whose constituent verb is related to the concept of PLANTS, more specifically, to plants in general (plant), plant parts (root, stem, bud, stump), stages of plant growth (sprout, shoot, blossom, branch, wither), stages of plant cultivation (prune, plough, weed, pot) and specific plants (mushroom, nut, bush, hedge). The following phrasal verbs are included in the analysis: root out, weed out, sprout out, stem out, bud out, prune out, mushroom out, nut out, plant out, blossom out, bush out, branch out, branch off, stump off, plant up, root up, pot up, shoot up, hedge in, plough through, root through and wither away. The aim of the analysis is to explore the conceptual scenes that underlie the meaning of English phrasal verbs related to plants as well as to shed light on the relation between the meaning of simple verbs and phrasal verbs related to the concept of PLANTS. Data used in the analysis were collected from the Oxford Phrasal Verbs, Dictionary for Learners of English, $2^{\text {nd }}$ edition (OXD) and the representative corpora, namely, the British National Corpus (BNC) and the Corpus of Contemporary American English (COCA), and included 1,282 examples in total. In investigating the semantics of the aforementioned set of phrasal verbs, we have relied on the cognitive semantic approach, which will be briefly outlined in the next section of the paper.

\section{The Cognitive Semantic Approach to Phrasal Verbs}

The cognitive approach to investigating the semantic structure of phrasal verbs entails studying their meaning with respect to conceptualization, semantic motivation and mutual relations between the constituent verb and particle. It casts new light onto the semantics of phrasal verbs, especially onto constituent particles, whose conceptual structure and consequently the meaning can be explained in terms of spatial schematization (Talmy 1983, 2000) or conceptual profiling (Langacker 1987, 1999, 2013). One portion of the conceptual scene is marked out for primary focus, and its spatial disposition is characterized in terms of the second portion (Talmy 2000: 182). The primary focus in the profiled relationship is designated as the TRAJECTOR, while the entity made prominent as the secondary focus is designated as the LANDMARK (Langacker 1987). Vital in this process is the concept of an image schema, "the recurring, dynamic pattern of our perceptual interactions and motor programs that gives coherence and structure to our experience" (Johnson 1987: XIV), such as CONTAINMENT, VERTICALITY, PATH, SUPPORT, etc. The internal structure of image schemas "locates the position of a trajector relative to a landmark and produces their basic 'logic' which gives rise to inference patterns" (Hampe 2002: 187).

The approach was used successively in a number of cognitive semantic analyses of the semantic motivation of phrasal verbs, such as Lindner's (1981) study of the English verbparticle constructions with the particles OUT and UP, Morgan's (1997) analysis of the senses of the verb figure out, Hampe's (2000) account of meaning extension of the verb face up to, Rudzka-Ostyn's (2003) study which focused on enhancing the process of learning of 
English phrasal verbs ${ }^{1}$, Milošević's (2016) investigation of the semantic structure of the English phrasal verbs containing particles IN, OUT, ON and OFF, etc., as well as in research dealing with prepositions, e.g. denoting CONTAINMENT (Klikovac 2000). These studies have shown that phrasal verbs usually have a number of related senses, which "form a radially structured category, with a central member and links defined by image schema transformations and metaphors" (Lakoff 1987: 460). Some of the recent studies in the field also include those dealing with the possible implications of the analysability of phrasal verbs for EFL learners and facilitating their retention by raising awareness about the metaphors underlying various senses (e.g. Boers \& Demecheleer 1998; Boers 2000, 2013; Đurović 2009, 2017; Milošević 2014; Porto Requejo \& Pena Díaz 2008; Vujić 2013; etc.). In a similar research to the present one, Đurović (2010) explored a number of English phrasal verbs whose constituent verb is related to animals, concluding that the metaphorical meanings of animal phrasal verbs should be taught alongside the basic prototypical meaning of verbs and particles in order to enhance their learning. Some dictionaries also aim at raising learners' awareness of the motivation of the metaphorical extensions of phrasal verb meanings - for instance, Macmillan Phrasal Verbs Plus (2005) is organized in such a way as to emphasize the relationships between different meanings of particles, both literal and figurative.

Conceptual metaphor has been postulated as a central mechanism both in investigating polysemy and the link between language and cognition and entails structuring the target domain in terms of the source, along with establishing correspondences between the elements of the two experiential domains (Lakoff \& Johnson 1980; Lakoff 1987; Evans \& Green 2006; etc.). Conceptual metonymy also proved to be an essential cognitive mechanism in meaning extension and encompasses the use of an entity to denote another entity which is logically related to the first one (Rasulić 2010: 51). When it comes to verbs and meaning extension via conceptual metonymy, particularly important are action $\mathrm{ICMs}^{2}$, which include a number of participants which may be related to the action or to each other (Kövecses \& Radden 1998: 54). Their relations may be manifested as different types of metonymy, so that the action ICM includes these types of metonymic relations (Kövecses \& Radden 1998: 54-55): INSTRUMENT FOR ACTION, AGENT FOR ACTION, ACTION FOR AGENT, OBJECT INVOLVED IN AN ACTION FOR THE ACTION, ACTION FOR OBJECT INVOLVED IN THE ACTION, RESULT FOR ACTION, ACTION FOR RESULT, MEANS FOR ACTION, MANNER OF ACTION FOR THE ACTION, TIME PERIOD OF ACTION FOR THE ACTION, DESTINATION FOR MOTION and TIME OF MOTION FOR AN ENTITY INVOLVED IN THE MOTION. Additionally, when exploring the role of metonymy in phrasal verb meaning the role of noun-verb conversions as metonymic relationships proves to be very significant (Kövecses \& Radden 1998: 60).

As far as the phrasal verbs under investigation in this paper are concerned, we opted for those whose constituent verb is related to the domain of PLANTS. It has been proven that this experiential domain serves as the source domain for conceptualizing a variety of target domains since plants are omnipresent and practically universal in human experience. The mappings from the source domain of PLANTS have been explored in several languages, predominantly English (Kövecses 1999, 2002) but also Serbian (Vesić 2007; Vesić Pavlović

\footnotetext{
${ }^{1}$ Rudzka-Ostyn's study (2003) was performed on the examples of 17 different particles featured in English phrasal verbs.

${ }^{2}$ ICM stands for an idealized cognitive model, defined by Lakoff (1987) as a complex, structured whole which serves to organize our knowledge; "category structures and prototype effects are by-products of that organization" (Lakoff 1987: 69).
} 
2008; Đurović \& Silaški 2010) or Mandarin Chinese (Lai \& Ahrens 2001). The major metaphor underlying the mappings related to plants is COMPLEX ABSTRACT SYSTEMS ARE PLANTS (Kövecses 1999, 2002). There are two primary metaphors at the root of this metaphor: ABSTRACT STRUCTURE IS PHYSICAL STRUCTURE and ABSTRACT DEVELOPMENT IS PHYSICAL GROWTH (Kövecses 1999: 181). The correspondences between the source domain of PLANTS and the target concepts may be related to plant parts (for instance, origins or causes may be conceptualized as roots or stems), stages of plants growth (e.g. the initial stages of the system development may be construed as the beginning of plant's growth, the best stage in the development of a complex system may be structured as the flowering of a plant, the unsuccessful or inappropriate development of a complex system may be construed as the unhealthy growth of a plant, etc.) or activities in plant cultivation (maintaining or taking care of complex system is structured as cultivating a plant, reducing complex systems is pruning, etc.).

The aforementioned metaphors are related to the extension of meaning of the majority of verbs which form constituent parts of the phrasal verbs under examination in this paper. Hence, we will attempt to shed light on whether and to what extent these conceptual metaphors motivate the use of the examined phrasal verbs. On the other hand, the examined phrasal verbs feature different constituent particles, namely, OUT, OFF, UP, THROUGH, IN and AWAY, and their meaning arises as the combination of the senses of particles and the constituent verbs. The findings of previous studies relevant for the meaning of these particles will be featured in the sections of the paper dealing with the particular verbs, respectively. In the following section, we will focus on research results, i.e. provide an account of spatial configurations which underlie the general meaning of these phrasal verbs as well as other numerous conceptual mechanisms responsible for motivating their specific meanings, using illustrative examples from the corpora.

\section{RESEARCH RESULTS}

\subsection{Plant phrasal verbs with the particle ouT}

The first group of verbs investigated in the paper includes those with the particle OUT: root out, weed out, sprout out, stem out, bud out, prune out, mushroom out, nut out, plant out, blossom out, bush out and branch out. Previous studies have established that the meanings of phrasal verbs containing the particle OUT can be related to the concept of CONTAINMENT (Lindner 1981, Milošević 2016). ${ }^{3}$ Our analysis has shown that, according to the meaning coded by the particles, we can further distinguish between four distinct sets of verbs within this group.

The first set of phrasal verbs with the particle OUT comprises sprout out, stem out, bud out, mushroom out and nut out. As shown by the examples recorded in the corpus, they have the general abstract meaning of ACCESSIBILITY. The semantic structure of these phrasal verbs is primarily motivated by the spatial configuration THE TRAJECTOR LEAVING

\footnotetext{
${ }^{3}$ Lindner (1981) singled out three basic prototypical schematic structures motivating the meanings of almost all phrasal verbs containing the particle OUT, which she labelled as OUT-1, OUT-2 and OUT- 3 . These were further elaborated and complemented by Milošević (2016). The schematic structure OUT-1 profiles a series of configurations between two concrete or abstract objects (trajector and landmark); OUT-2 profiles the change of shape of a single object, that is, the different parts or locations of the same entity (trajector = landmark); OUT-3 profiles a movement of an entity (trajector) away from a source or point of origin (landmark).
} 
THE BOUNDARIES OF THE LANDMARK (Figure 1), which underlies the conceptual-semantic structure of the constituent particle OUT. Additionally, the abstract meaning of ACCESSIBILITY results from the correspondences established between the conceptual metaphor ABSTRACT STRUCTURE IS PHYSICAL STRUCTURE, that is, its submetaphor ABSTRACT COMPLEX SYSTEMS ARE PLANTS and the spatial configuration THE TRAJECTOR LEAVING THE BOUNDARIES OF THE LANDMARK.

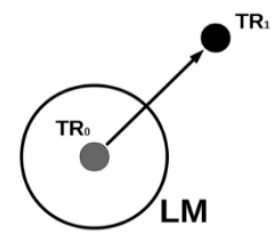

Fig. 1 The trajector leaving the boundaries of the landmark

Regarding the specific meanings of the phrasal verbs sprout out, stem out and bud out, they come from the conceptual metonymy MANNER OF ACTION FOR THE ACTION (Kövecses \& Radden 1998: 60-61), which is responsible for the semantic interaction between the two constituent components (the verb and the particle). Furthermore, the following structural metaphors, inherent in the constituent verb, are characteristic of the meaning extension of this set of verbs: THE QUICK DEVELOPMENT OF A LARGE NUMBER OF THINGS IS THE QUICK GROWTH OF A LARGE NUMBER OF SHOOTS AND LEAVES (sprout out), ORIGINS OR CAUSES LEADING TO EFFECTS ARE PARTS OF PLANTS FROM WHICH OTHER PLANTS GROW (stem out) and THE INITIAL STAGES OF DEVELOPMENT ARE THE BEGINNINGS OF GROWTH (bud out) (Kövecses 1999). The following examples illustrate concrete (examples 1, 2) and abstract senses (examples $3,4,5,6$ ) of this group of phrasal verbs with the particle OUT.

(1) Tory asked suddenly, pointing down to a strand of granite pebbles by which a group of bright blooms apparently sprouted out of the shallow water. (BNC)

(2) The mulberry trees are budding out now. You know how bad that pollen can be. (COCA)

(3) All the memories that were still in the bottom of my brain, they all just sprouted out. (BNC)

(4) Glasgow grew ever outwards in the thirties, swallowing up the countryside in huge bites as poured-concrete bungalows sprouted out of the fields of Newlands, Merrylee, Cathcart, and all points south. (BNC)

(5) Indeed, the various government White Papers that preceded the reorganisation of individual social services gave implicit support to this feeling of vague egalitarianism stemming out of universalism. (BNC)

(6) Cutting off the supply of nutrition to tissues in any part of the body has a further consequence - new blood vessels bud out from the already dilated vascular bed to make up nutritional deficit. (BNC)

However, the specific meanings of the phrasal verbs mushroom out and nut out stem from a different conceptual metonymy OBJECT INVOLVED IN AN ACTION FOR THE ACTION, also identified by Kövecses and Radden (1998: 60-61). Furthermore, their specific meanings are a 
result the co-occurrence of the above-mentioned metonymy and the conventional knowledge ${ }^{4}$ that one has about "mushrooms" being prone to growing rapidly in large numbers in the first case, and "nuts" being tough to crack in the second case.

(7) 'We are going through the process of making forensic tests and taking statements, which may take some time, and the inquiry is now mushrooming out from the house.' (BNC)

(8) I'm going to have to nut it out on a piece of paper. (OXD)

The meaning of the second set of phrasal verbs with the particle OUT - weed out, root out and prune out - is modelled on a different spatial configuration, SEPARATION/REMOVAL OF THE TRAJECTOR FROM THE LANDMARK (Figure 2).

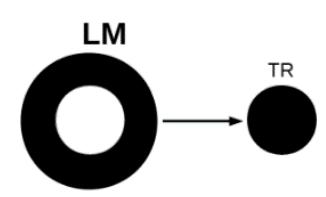

Fig. 2 Separation/removal of the trajector from the landmark

This spatial configuration is responsible for numerous concrete and abstract senses. On the one hand, one can speak of the physical removal/separation of parts from the whole (e.g. parts of plants/trees removed from the whole plant/tree, examples 9, 10). On the other hand, the general abstract meanings of EXCLUSION and ELIMINATION/ERADICATION, which have also been recorded in the instances from the corpus (examples 11, 12, 13), are motivated by the correspondences formed between various abstract domains (e.g. IDEAS, SOCIETY, HUMAN INTERACTIONS) and the spatial configuration SEPARATION/REMOVAL OF THE TRAJECTOR FROM THE LANDMARK via the following submetaphors of the metaphor COMPLEX ABSTRACT SYSTEMS ARE PLANTS: TO MAINTAIN OR TO TAKE CARE OF COMPLEX SYSTEM IS TO CULTIVATE A PLANT (weed out), ORIGINS OR CAUSES LEADING TO EFFECTS ARE PARTS OF PLANTS FROM WHICH OTHER PLANTS GROW (root out) and REDUCING COMPLEX SYSTEMS IS MAKING PLANTS SMALLER (prune out) (Kövecses 1999). Concerning the specific meanings of the phrasal verbs in question, they come from the metonymy MANNER OF ACTION FOR THE ACTION. The examples provided below illustrate concrete and abstract senses of this set of phrasal verbs featuring the particle OUT.

(9) One of the fields had been ploughed and our job was to weed out the wiry roots and tufts of grass that the wooden ploughshare had failed to dislodge so that the field could be smoothed out ready for flooding. (BNC)

(10) In fact, we have pruned out those parts of the tree which could be grown from node 8 . (BNC)

(11) The good trainees were thus encouraged. The useless ones were soon weeded out. (BNC)

(12) The government has promised to root out police corruption. (OXD)

(13) The probability score can also improve the efficiency of the parsing algorithm by pruning out low-probability alternatives. (OXD)

\footnotetext{
${ }^{4}$ Kövecses and Szabó (1996) introduce conventional knowledge as a third cognitive mechanism (along with the conceptual metaphor and conceptual metonymy), which motivates the meaning of linguistic units such as idioms.
} 
The third identified case of phrasal verbs with the particle OUT is represented by only one verb, plant out. The semantic structure of this phrasal verb stems from the spatial configuration DISTRIBUTION OF THE TRAJECTOR OUTSIDE THE LANDMARK (Figure 3), corroborated by the corpus-based example below (example 14).

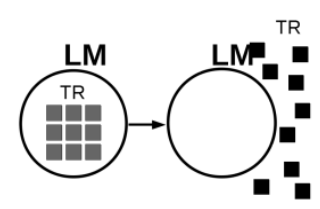

Fig. 3 Distribution of the trajector outside the landmark

Similarly to the previous cases, the conceptual metonymy MANNER OF ACTION FOR THE ACTION motivates the semantic interaction between the constituent verb and the constituent particle, and is thus responsible for the specific meaning of the whole phrasal verb.

(14) Thin seedlings and plant out in autumn. (BNC)

Unlike the previous three cases, the meaning of the fourth set of phrasal verbs with the particle OUT including the verbs bush out, blossom out and branch out relies on the spatial configuration in which the trajector and the landmark embody the different locations of the same entity (the so-called reflexive trajector - Lindner 1981, Lakoff 1987). In particular, their conceptual-semantic structure stems from the spatial configuration THE TRAJECTOR INCREASING TO ITS MAXIMAL BOUNDARIES (Figure 4).

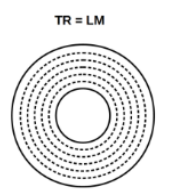

Fig. 4 The trajector increasing to its maximal boundaries

In the instances from our corpus, this spatial configuration motivates both concrete (examples 15, 16) and abstract meanings of these verbs (e.g. the abstract meaning of DIVERSIFICATION in the case of the phrasal verb branch out, illustrated by example 17, or the abstract meaning of EXPANSION TO THE FULL OR CANONICAL FORM, in the case of the phrasal verb blossom out, illustrated by example 18). On the other hand, the specific meanings result from the conceptual metonymies MANNER OF ACTION FOR THE ACTION (in the case of branch out and blossom out) and RESULT FOR ACTION (in the case of bush out). The abstract meanings further stem from the following submetaphors of the COMPLEX ABSTRACT SYSTEMS ARE PLANTS metaphor: THE QUICK DEVELOPMENT OF A LARGE NUMBER OF THINGS IS THE QUICK GROWTH OF A LARGE NUMBER OF SHOOTS AND LEAVES (bush out), A COMPLEX SYSTEM BECOMING LARGER IS THE PLANT GROWING BIGGER (branch out) and THE BEST STAGE IN THE PROGRESS OR DEVELOPMENT OF A COMPLEX SYSTEM IS THE FLOWERING OF A PLANT (blossom out) (Kövecses 1999). The following examples illustrate both concrete and abstract meanings recorded in the corpus for these verbs. 
(15) Once the plants branch out and grow thick, they can be pruned to keep them under control and stimulate new growth. (BNC)

(16) Then the plants will bush out, putting forth fresh shoots at frequent intervals. (BNC)

(17) The company is branching out into Europe. (OXD)

(18) But he suddenly seemed to blossom out and take weight, like a ghost deciding to cross back over the frontier from the land of death. (BNC)

\subsection{Plant phrasal verbs with the particle OFF}

Our analysis has shown that there are three distinct cases when it comes to the phrasal verbs with the particle OFF which are examined in this paper. It has been argued previously that the meaning of phrasal verbs containing this particle can be related to the concept of

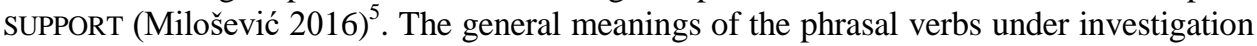
result from three different spatial configurations underlying the semantics of the constituent particle - SEPARATION AND MOVING/ORIENTING OF THE TRAJECTOR, LINEAR SPREADING OF THE TRAJECTOR and DEVIATION OF THE TRAJECTOR FROM THE LANDMARK.

The first case refers to the phrasal verb stump off, with the concrete meaning of walking, hitting the ground hard as you go (OXD). Its general meaning stems from the spatial configuration SEPARATION AND MOVING/ORIENTING OF THE TRAJECTOR (Figure 5), whereas the specific meaning results from the conceptual metonymy OBJECT INVOLVED IN AN ACTION FOR THE ACTION, which is inherent in the conceptual structure of the constituent verb to stump (example 19).

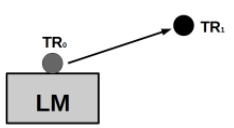

Fig. 5 Separation and moving/orienting of the trajector

(19) He stumped off, muttering under his breath. (OXD)

The second case can be illustrated by the phrasal verb branch off, which has the following concrete meaning "to leave a larger one and go in a different direction (typically of roads, paths, etc.)" (OXD). The general meaning of this verb is derived from the spatial scene LINEAR SPREADING OF THE TRAJECTOR, underlying the semantics of the constituent particle OFF (Figure 6) and it is illustrated by example 20.

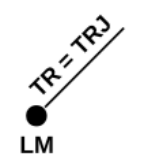

Fig. 6 Linear spreading of the trajector

\footnotetext{
${ }^{5}$ Milošević (2016) distinguished four prototypical schematic structures motivating the majority of the phrasal verbs containing the particle OFF: OFF-1 - the loss of support (the trajector not being supported by the landmark any longer); OFF- 2 - the separation of the part (the trajector) from the whole (the landmark); OFF- 3 - the linear spreading of the trajector; OFF- 4 - the trajector deviating from the landmark.
} 
(20) She followed the path until it branched off. (OXD)

Finally, the third case of different senses of phrasal verbs with the particle OFF ascertained in the examined set of verbs can also be exemplified by the phrasal verb branch off, but in the following sense "to leave a road or path and travel in different direction (typically people)" (OXD). Its general meaning stems from the spatial configuration DEVIATION OF THE TRAJECTOR FROM THE LANDMARK (Figure 7), which can be illustrated by example 21 .

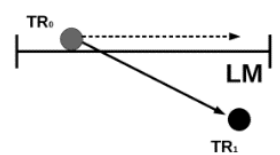

Fig. 7 Deviation of the trajector from the landmark

(21) Go past the farm and branch off towards the trees. (OXD)

\subsection{Plant phrasal verbs with the particle UP}

Generally speaking, the main sense of the particle UP involves "orientation of the TR and the LM along the vertical dimension" (Tyler \& Evans 2003: 135), and hence the meaning of the phrasal verbs with this particle can be related to the concept of VERTICALITY. Our analysis has shown that we can speak of three distinct cases when it comes to the phrasal verbs with the particle UP within the PLANT domain recorded in our corpus. ${ }^{6}$

The first case, encompassing the phrasal verbs plant up and pot up, is predominantly semantically motivated by the spatial scene THE TRAJECTOR MOVING UPWARDS WITHIN THE BOUNDARIES OF THE LANDMARK (Figure 8), which stems from the conceptual framework of the constituent particle UP. ${ }^{7}$

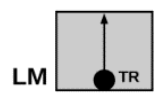

Fig. 8 The trajector moving upwards within the boundaries of the landmark

It is interesting to note that all the meanings of these two phrasal verbs recorded in the corpus are concrete meanings, that is, no abstract/metaphorical meanings have been detected. Their specific meanings result from two conceptual metonymies, MANNER OF ACTION FOR THE ACTION (in the case of the verb plant up, illustrated by example 21) and OBJECT INVOLVED IN AN ACTION FOR THE ACTION (in the case of the verb pot up, illustrated by example 22).

\footnotetext{
${ }^{6}$ All the phrasal verbs with the particle UP analysed in the paper can be subsumed under the schematic structure which Lindner (1981:148) labelled as 'Vertical UP', as opposed to the so-called 'Goal-oriented UP'.

${ }^{7}$ This sense corresponds to what Tyler and Evans (2003: 139) refer to as the Completion sense of the particle UP, which entails that during an increase of quantity usually a certain limit is reached beyond which there can be no further increase.
} 
(21) By planting up large containers with a mixture of varieties, a succession of colours can be achieved. (BNC)

(22) Pot them up in September, and bring into the greenhouse for winter flowers. (BNC)

The second case involves the phrasal verb shoot up. Namely, its semantic structure is primarily motivated by the following spatial configuration underlying the semantics of the constituent particle UP - THE TRAJECTOR MOVING UPWARDS BEYOND THE BOUNDARIES OF THE LANDMARK (Figure 9). ${ }^{8}$

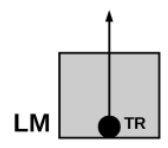

Fig. 9 The trajector moving upwards beyond the boundaries of the landmark

Similarly to the case of the verbs plant up and pot up, the specific meaning of the whole phrasal verb shoot up comes from the conceptual metonymy, MANNER OF ACTION FOR THE ACTION, which stems from the constituent component to shoot (examples 23, 24). Furthermore, the abstract meaning of GROWTH, which is realized by this phrasal verb, is an immediate result of the conceptual metaphor THE QUICK DEVELOPMENT OF A LARGE NUMBER OF THINGS IS THE QUICK GROWTH OF A LARGE NUMBER OF SHOOTS AND LEAVES, inherent in the constituent verb.

(23) She shot up in the last few months. (OXD)

(24) The inflation rate shot up to $20 \%$. (OXD)

The third case has been recorded in the meaning of the phrasal verb root up. Its general meaning comes from the spatial configuration PULLING THE TRAJECTOR UPWARDS BEYOND THE BOUNDARIES OF THE LANDMARK (Figure 10), underlying the semantic framework of the particle UP, illustrated by example 25 .

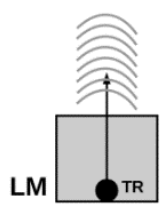

Fig. 10 Pulling the trajector upwards beyond the boundaries of the landmark

The specific meaning is motivated by the conceptual metonymy OBJECT INVOLVED IN AN ACTION FOR THE ACTION, which structures the conceptual-semantic framework of the constituent component to root. Moreover, the abstract meaning of DISCOVERY of this phrasal verb (example 26) is extended by means of the structural metaphor ORIGINS OR

\footnotetext{
${ }^{8}$ This sense may be related to a conventionalized More sense of the particle UP (Tyler \& Evans 2003), which arises due to the situations in everyday experience where "an increase in vertical elevation correlates with an increase in quantity" (Tyler \& Evans 2003: 138).
} 
CAUSES LEADING TO EFFECTS ARE PARTS OF PLANTS FROM WHICH OTHER PLANTS GROW, which underlies the semantic structure of the PLANT domain component root.

(25) Kids have been rooting up plants. (OXD)

(26) Certainly this is a month of trials and tribulations but I suspect what will be rooted up, thrashed out and spat out will do us all a favour in the end. (BNC)

\subsection{Plant phrasal verbs with the particle THROUGH}

Two phrasal verbs with the particle THROUGH were analysed: plough through and root through. The general conceptual-semantic structure of both phrasal verbs, having either concrete or abstract senses, results from the conceptual scene THE TRAJECTOR MOVING THROUGH THE LANDMARK FROM END TO END (Rudzka-Ostyn 2003: 195), which underlies the conceptual framework of the constituent particle THROUGH (Figure 11).

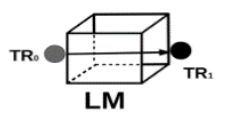

Fig. 11 The trajector moving through the landmark from end to end

When it comes to the abstract meaning of MAKING PROGRESS WITH DIFFICULTY, it is extended via the metaphor TO MAINTAIN OR TO TAKE CARE OF COMPLEX SYSTEM IS TO CULTIVATE A PLANT (plough through, examples 27, 28) and ORIGINS OR CAUSES LEADING TO EFFECTS ARE PARTS OF PLANTS FROM WHICH OTHER PLANTS GROW (root through, example 29). On the other hand, specific meanings stem from the conceptual metonymy OBJECT INVOLVED IN AN ACTION FOR THE ACTION, underlying the constituent components plough and root.

(27) The car lurched to the right, mounted the grass verge, and ploughed through the safety barrier. (BNC)

(28) Having admired his free verse for some years I had recently ploughed through his somewhat monumental work, the first two volumes of 'Abraham Lincoln The Prairie Years' and enjoyed it. (BNC)

(29) He had been rooting through the rubbish. (OXD)

\subsection{Plant phrasal verbs with the particle IN}

Regarding the phrasal verbs containing the particle IN within the domain of PLANTS, there is only one phrasal verb - hedge in. Both its concrete sense ("to physically surround sb/sth with sth", OXD) and the abstract sense of ISOLATION/RESTRICTION ("to restrict the freedom of sb to do sth", OXD) are primarily motivated by the spatial configuration SURROUNDING OF THE TRAJECTOR (Figure 12). In addition, the specific meaning of this phrasal verb is a result of the conceptual metonymy OBJECT INVOLVED IN AN ACTION FOR THE ACTION, contained within the conceptual-semantic structure of the PLANT domain component hedge. 


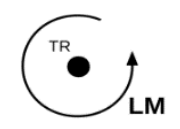

Fig. 12 Surrounding of the trajector

The concrete and abstract meaning can be illustrated by the following examples:

(30) The cathedral is hedged in by other buildings. (OXD)

(31) He felt hedged in by all the rules and regulations. (OXD)

\subsection{Plant phrasal verbs with the particle AWAY}

One phrasal verb with the particle AWAY discovered in the domain of PLANTS, wither away, in all the recorded examples in the corpus has the abstract meaning of DISAPPEARANCE. The general meaning is modelled on the spatial scene THE TRAJECTOR LEAVING AND NOT BEING AT THE LANDMARK (Rudzka-Ostyn 2003: 139), underlying the conceptual structure of the particle AWAY (Figure 13), which is further extended via the metaphor THE UNSUCCESSFUL OR INAPPROPRIATE DEVELOPMENT OF A COMPLEX SYSTEM IS THE UNHEALTHY GROWTH OF A PLANT, stemming from the conceptual structure of the constituent component to wither. As regards the specific meaning of the whole phrasal verb, it comes from the conceptual metonymy MANNER OF ACTION FOR THE ACTION, inherent in the constituent verb to wither.

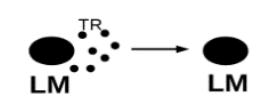

Fig. 13 The trajector leaving and not being at the landmark

(32) From then on it was the 'Dark Ages' when nothing seemed to happen at all. One almost had the feeling that the population must have withered away and vanished.

(33) Programmes would wither away if they did not command sufficient local support.

\section{DISCUSSION AND CONCLUDING REMARKS}

In this paper, within the cognitive semantic framework, we have examined the semantics of a set of English phrasal verbs whose constituent verb is related to the experiential domain of PLANTS, such as plant parts, stages of plant growth and cultivation, the plant in general, and some specific plants, using dictionary-based and corpus-based examples. Based on the analysis, we can conclude that the concrete and abstract senses of the investigated verbs arise from the interaction of the meaning of the constituent verb and a certain sense of the particle, which is motivated by various cognitive mechanisms underlying their conceptual-semantic structure. The general meaning of the phrasal verbs under examination results from different spatial configurations (scenes) which underlie the conceptual-semantic structure of the constituent particles (OUT, OFF, UP, IN, THROUGH and AWAY). In all the cases, the specific meanings of the investigated phrasal verbs are motivated by different conceptual metonymies stemming from the constituent verb, such as 
MANNER OF ACTION FOR THE ACTION, RESULT FOR ACTION and OBJECT INVOLVED IN AN ACTION FOR THE ACTION, and simultaneously are responsible for the semantic interaction between the constituent particle and the constituent verb. Finally, numerous metaphorical/ abstract meanings of the observed phrasal verbs are structured via various submetaphors of the basic metaphor COMPLEX ABSTRACT SYSTEMS ARE PLANTS (e.g. ORIGINS OR CAUSES LEADING TO EFFECTS ARE PARTS OF PLANTS FROM WHICH OTHER PLANTS GROW - root out, root up, THE INITIAL STAGES OF DEVELOPMENT ARE THE BEGINNINGS OF GROWTH - bud out, A COMPLEX SYSTEM BECOMING LARGER IS THE PLANT GROWING BIGGER - branch out, REDUCING COMPLEX SYSTEMS IS MAKING PLANTS SMALLER - prune out, etc.), which are embedded in the conceptual framework of the constituent verbs, that is, the linguistic elements belonging to the domain of PLANTS (root, bud, branch, prune, etc.). Our findings thus suggest that, in the case of phrasal verbs whose constituent verb is related to PLANTS, the analysis of meaning needs to take into account the complex interplay between the senses of the particle relying on spatial configurations and the senses of the constituent verb stemming from the conceptual metaphor and metonymy.

Finally, the established mechanisms of meaning construction in the examined phrasal verbs may have implications for their learning. In previous studies, it has been shown that "enhanced awareness of the conceptual metaphors behind figurative expression leads the learners to use the strategy of visualizing idioms in terms of conceptual metaphors and consequently involves them in deep cognitive processing, which increases the probability of memory storage" (Yasuda 2010: 252). Since the domain of PLANTS and its entailments are well known from ordinary experience and, it may be argued, quite convenient for visualizing, the additional awareness of the semantic motivation of the meaning of the phrasal verbs related to the concept of PLANTS may facilitate the acquisition of these lexical units.

\section{SOURCES}

British National Corpus (BNC). http://corpus.byu.edu/bnc.

Corpus of Contemporary American English (COCA). http://corpus.byu.edu/coca.

Oxford Phrasal Verbs, Dictionary for Learners of English (OXD), $2^{\text {nd }}$ edition (2006), Oxford University Press.

\section{REFERENCES}

Anastasijević, K., (1968), Dvočlani glagoli u savremenom engleskom jeziku, Filološki fakultet, Beograd.

Boers, F., (2000), "Metaphor Awareness and Vocabulary Retention", Applied Linguistics 21, Vol. 4: pp. 553571. doi:10.1093/applin/21.4.553

Boers, F., (2013), "Cognitive Linguistic Approaches to Teaching Vocabulary", Language Teaching 46, Vol. 2: pp. 208-224. doi:10.1017/S0261444811000450

Boers, F., and Demecheleer, M., (1998), "A Cognitive Semantic Approach to Teaching Prepositions", ELT Journal 52, Vol. 3: pp. 197-204. doi:10.1093/elt/52.3.197

Brugman, C., (1981), Story of Over, Master Thesis, University of California, Berkeley.

Đurović, T., (2009), "A Cognitive Approach to Business English Phrasal Verbs: The Case of Out", Primenjena lingvistika 10: pp. 207-218.

Đurović, T., (2010), "Beavering away or Monkeying around: Metaphoricity of Phrasal Verbs Related to Animals", In: Raţă, G., (Ed.), Teaching foreign languages: Languages for special purposes, pp. 330-342, Cambridge Scholars Publishing, Cambridge. 
Đurović, T., (2017), Engleski jezik ekonomske nauke i struke u svetlu kognitivne lingvistike, CID Ekonomskog fakulteta, Beograd.

Đurović, T., and Silaški, N., (2010), "Koreni i procvat korupcije - Konceptualizacija korupcije kao BILJKE u javnom diskursu Srbije", U: Mišić Ilić B. and Lopičić, V., (ur.), Jezik, književnost, promene. Jezička istraživanja. Zbornik radova, str. 200-216, Filozofski fakultet, Niš.

Evans, V., and Green, M., (2006), Cognitive Linguistics: An Introduction, Lawrence Erlbaum Associates/Edinburgh University Press, Hillsdale, NJ/Edinburgh.

Fraser, B., (1976), The Verb-Particle Combination in English, Academic Press, New York.

Hampe, B., (2000), "Facing up to the Meaning of 'Face up to'", In: Foolen, A. and van der Leek, F., (eds.), Constructions in Cognitive Linguistics, pp. 81-101, John Benjamins, Amsterdam.

Hampe, B., (2002), Superlative Verbs: A Corpus Based Study of Semantic Redundancy in English Verb Particle Constructions, Gunter Narr Verlag, Tübingen.

Johnson, M., (1987), The Body in the Mind: the Bodily Basis of Meaning, Imagination, and Reason, The University of Chicago Press, Chicago.

Klikovac, D., (2000), Semantika predloga. Studija iz kognitivne lingvistike, Filološki fakultet, Beograd.

Kövecses, Z., (1999), "Metaphor: Does It Constitute or Reflect Cultural Models?", In: Steen, G. and Gibbs, R., (eds.), Metaphor in Cognitive Linguistics, pp. 167-188, John Benjamins, Amsterdam and Philadelphia.

Kövecses, Z., (2002), Metaphor: A Practical Introduction, Oxford University Press, New York.

Kövecses, Z., and Radden, G., (1998), "Metonymy: Developing a cognitive linguistic view", Cognitive Linguistics 9, Vol. 1: pp. 37-79. doi: 10.1515/cogl.1998.9.1.37

Kövecses, Z., and Szabó, P., (1996), "Idioms. A View from Cognitive Semantics", Applied Linguistics 17, Vol. 3: pp. 326-355. doi: 10.1093/applin/17.3.32

Lai, V. T., and Ahrens, K., (2001), "Mappings from the Source Domain of Plant in Mandarin Chinese", In: T'sou, B.K., Kwong, O.O. and Lai, T.B., (eds.), Proceedings of the $15^{\text {th }}$ Pacific Asia Conference on Language Information and Computation, pp. 203-209, City University of Hong Kong, Hong Kong.

Lakoff, G., (1987), Women, Fire and Dangerous Things, Chicago University Press, Chicago.

Lakoff, G., and Johnson, M., (1980), Metaphors We Live By, University of Chicago Press, Chicago.

Langacker, R., (1987), Foundations of Cognitive Grammar, Vol. I: Theoretical Prerequisites, Stanford University Press, Stanford.

Langacker, R., (1999), Grammar and Conceptualization, Mouton de Gruyter, Berlin.

Langacker, R., (2013), Essentials of Cognitive Grammar, Oxford University Press, Oxford.

Lindner, S., (1981), A Lexico-Semantic Analysis of English Verb-Particle Constructions with UP and OUT, Doctoral Dissertation, University of California, San Diego.

Live, A. H., (1965), "The Discontinuous Verb in English", Word 21: pp. 428-451.

Milošević, I., (2014), "The Role of Cognitive Mechanisms and Semantic Motivation in Business English Idioms Acquisition - an Experimental Study", In: Akbarov, A., (ed.), FLTAL '14 (Applying Intercultural Linguistic Competence to Foreign Language Teaching and Learning), Vol. 1, pp. 1103-1111, International Burch University, Sarajevo.

Milošević, I., (2016), Frazni glagoli sa partikulama IN, OUT, ON $i$ oFF u engleskom jeziku: kognitivnolingvistička analiza, Doktorska disertacija, Filološki fakultet, Beograd.

Morgan, P. S., (1997), "Figuring out figure out: Metaphor and the Semantics of English Verb Particle Construction", Cognitive Linguistics 8, Vol. 4: pp. 327-357. doi: 10.1515/cogl.1997.8.4.327

Porto Requejo, M.D., and Pena Díaz, C., (2008), "A Cognitive Approach to Some Phrasal Verbs in English for Specific Purposes", Ibérica 16: pp. 109-128.

Rasulić, K., (2010), "Aspekti metonimije u jeziku i mišljenju", Theoria 53, Vol. 3: pp. 49-70.

Rudzka-Ostyn, B., (2003), Word Power: Phrasal Verbs and Compounds: A Cognitive Approach, Mouton de Gruyter, Berlin.

Rundell, M., (2005), Macmillan Phrasal Verbs Plus, Bloomsbury Publishing, Oxford.

Talmy, L., (1983), "How Language Structures Space", In: Pick, H. L., and Acredolo, L.P., (eds.), Spatial orientation: Theory, research, and application, pp. 225-282, Plenum Press, New York.

Talmy, L., (2000), Toward a Cognitive Semantics (2 vols), MIT Press, Cambridge, MA.

Tyler, A., and Evans, V., (2003), The Semantics of English Prepositions. Spatial Scenes, Embodied Meaning and Cognition, Cambridge University Press, Cambridge.

Vesić, T., (2007), Metafore u engleskom i srpskom jeziku čiji je izvorni domen pojam BILJKE, Magistarski rad, Filološki fakultet, Beograd.

Vesić Pavlović, T., (2008), "How Do People Sprout, Blossom, Ripen and Wither? PEOPLE ARE PLANTS Metaphor in English and Serbian", In: Rasulić, K. and Trbojević, I., (eds.), ELLSSAC Proceedings, Vol. I, pp. 351-362, Filološki fakultet, Beograd. 
Vujić, J., (2013), "Sintaksički i leksičko-semantički status partikule kod nekih dvočlanih glagola u engleskom jeziku", U: N. Silaški and Đurović, T., (ur.), Aktuelne teme engleskog jezika nauke i struke u Srbiji, str. 4561, CID Ekonomskog fakulteta, Beograd.

Yasuda, S., (2010), "Learning Phrasal Verbs Through Conceptual Metaphors: A Case of Japanese EFL learners", TESOL Quarterly 44, Vol. 2: pp. 250-273. doi: 10.5054/tq.2010.219945

\section{KOGNITIVNOLINGVISTIČKA ANALIZA ENGLESKIH FRAZNIH GLAGOLA KOJI SE ODNOSE NA BILJKE}

U radu se razmatra značenje engleskih fraznih glagola čiji se sastavni glagol odnosi na BILJKE. Analizirana je značenjska struktura 22 frazna glagola sa partikulama OUT, OFF, UP, THROUGH, IN $i$ AWAY. Analiza je izvršena u okviru teorijskih postavki kognitivne lingvistike u kojoj se značenje fraznih glagola posmatra u kontekstu sastavnih partikula i semantičke interakcije između sastavnog glagola $i$ partikule. Zaključuje se da opšta značenja razmatranih fraznih glagola izviru iz različitih prostornih konfiguracija koje leže u osnovi pojmovno-značenjske strukture sastavnih partikula, dok su specifična značenja motivisana različitim pojmovnim metonimijama koje potiču od sastavnog glagola. Brojna apstraktna značenja dodatno proističu iz različitih podmetafora osnovne pojmovne metafore APSTRAKTNI SLOŽENI SISTEMI SU BILJKE, koja se nalazi u osnovi pojmovne strukture sastavnih glagola.

Ključne reči: frazni glagoli, biljke, kognitivna semantika, prostorne konfiguracije, pojmovni mehanizmi 